Slavische Literaturen“ an der FU Berlin. U. Bamborschke, W. Kośny, H. Meyer-Harder, W.-H. Schmidt, K.-D. Seemann. Berlin; Wiesbaden, 1979. (Veröffentlichungen der Abteilung für Slavische Sprachen und Literaturen des Osteuropa-Instituts [Slavisches Seminar] an der Freien Universität Berlin. Bd. 48).

Halperin C. A. Chingissid Saint of (sic.) Russian Orthodox Church: "The Life of Peter, Tsarevich of the Horde" // Canadian-American Slavic Studies. 1975. Vol. 9. № 3. P. 324-335.

Vernadsky G. The Mongols and Russia. New Haven, Conn., 1953.

\author{
Gail Lenhoff \\ University of California, Los Angeles, USA
}

\title{
THE TERM “GODOVNYE OBROKI” IN THE “TALE OF PETR, TSAREVICH OF THE HORDE”
}

The essay deciphers a puzzling reference to "yearly payments" provided by Khan Berke to the Rostov episcopal cathedral during the lifetime of Rostov Bishop Kirill II. Correcting and developing the historiography, it supplies indirect evidence that Bishop Kirill, a loyal supporter of Berke, ran into financial difficulties because - despite the many privileges granted clerics - essential sources of episcopal income were interrupted in the first half-century of Mongol rule. He went to the Horde to request help from the khan. Citing the precedent of the "desiatina," Berke agreed to supply Kirill with yearly payments during his lifetime, but forced the local princes to supply and deliver the payments.

Keywords: tithe, payments, tribute, census, Rostov, Mongol rule

УДК 929.522.1 ББК 63.3(0)4, 63.2, 63.214, 81.053.16 DOI 10.25986/IRI.2019.75.1.0015

А. Ф. Литвина

НИУ Высшая школа экономики, Москва, Россия. annalitvina@gmail.com

Ф. Б. Успенский

Институт славяноведения $Р$ АН,

НИУ Высшая школа экономики, Москва, Россия. fjodor.uspenskij@gmail.com

К УТОЧНЕНИЮ ИМЕН И ДАТ В СЕМЬЕ ЦАРЯ ФЕДОРА ИВАНОВИЧА ${ }^{1}$

Работа посвящена истории христианской двуименности в допетровской Руси. Основное внимание сосредоточено на позднем этапе функџионирования этой традиџии в династии Рюриковичей и у их ближайшего окружения. В статье обсуждаются следуюшие вопросы: какими христианскими именами обладали џарь Федор и џариџа Ирина, кого они почитали в качестве личных патрональных святых и когда Ирина Федоровна Годунова могла появиться на свет?

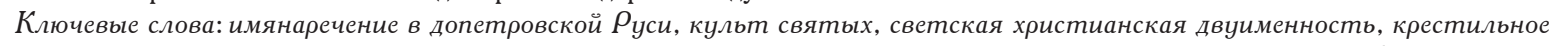
имя, день рождения, личные небесные покровители, заздравные и поминальные вклады, семья Ивана Грозного, иарь Федор Иванович, цуарица Ирина Годунова

Шестнадџатое столетие в истории московского правяшего дома ознаменовано постепенным угасанием практики мирской христианской двуименности. Проџесс этот протекал неравномерно и неоднозначно. Как и прежде, некоторые отпрыски великокняжеской, а затем и царской семьи получали по два календарных имени, тогда как другие оставались, по всей видимости, одноименными. В этом отношении семья Ивана Грозного мало чем отличалась, скажем, от семьи Дмитрия Донского, однако в перспективе функџионирования этих имен разниџа между правителями XIV и XVI в. была весьма значительной.

Сушественно упроџая дело, можно сказать, что если в XIV в. династу дается два светских христианских имени, то выбираются они следуюшим образом. Одно дается ему или ей по дате рождения, то есть в честь одного из тех святых, чья память празднуется в день появления такого династа на свет. Оно-то и становится именем крестильным, но при этом непубличным. Второе же имя - династическое, публичное - подбирается из числа традиџионных родовых имен в довольно широких календарных окрестностях даты рождения. Иными словами, князь мог быть

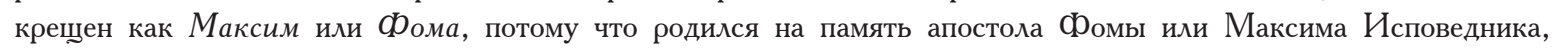
но правил как Дмитрий или Андрей, потому что это имя было в ходу у его предков, а празднование Дмитрию Солунскому или Андрею Стратилату отстояло от дня его рождения на несколько дней или даже на две-три недели [Литвина, Успенский, 2017; Литвина, Успенский, 2018а; Литвина, Успенский, 2018б; Литвина, Успенский, 2019]. Небесных покровителей у такого князя, естественным образом, оказывалось двое - свв. ФОома и Дмитрий или свв. Максим и Андрей.

При этом у носителя светской христианской двуименности могли быть родные братья и сестры, обладавшие всего одним христианским именем, совмешавшим в себе функџии публичного, династического и крестильного. Это единственное имя могло, счастливым образом, выпасть по календарю (ведь свв. Федоров, Андреев, Василиев, Иоаннов в месяџеслове довольно много, а все эти имена для Рюриковича были вполне пригодны) или быть подобранным по старинке, без столь уж жесткой оглядки на календарь, то есть практически так же, как это делалось

\footnotetext{
1 В работе использованы результаты проекта «Символическое поведение в Средние века и раннее Новое время», выполненного в рамках Программы фундаментальных исследований НИУ ВШЭ в 2018 г.
} 
еще в домонгольское время. О том, были ли склонны одноименные князья, нареченные по этой наиболее древней схеме, как-то особо почитать тех святых, чья память приходилась на их день рождения, мы практически ничего не знаем.

К XVI в. картина кардинально меняется. Можно сказать, что весомость календаря в имянаречении членов правящей семьи и возрастает и убывает одновременно. С одной стороны, для тех членов династии, кто обладал одним-единственным именем, выбранным не точно по дате появления на свет, мы наблюдаем все больше признаков почитания святых, связанных с днем их рождения. С другой стороны, у носителей двух христианских имен соотношение ролей мирских имен также не остается прежним - династическое имя, как и раньше, выбирается в широких календарных окрестностях дня рождения, но теперь оно же дается и в крешении. Второе же имя, соответствуюшее дню появления на свет непосредственно, остается своего рода благочестивым дополнением в такого рода антропонимической паре.

Таким образом, одноименность и двуименность в династическом обиходе неуклонно сближаются, граниџа между ними становится все более зыбкой. В результате, несмотря на то что письменных и материальных свидетельств, относящихся к XVI в., в нашем распоряжении несравненно больше, чем текстов и артефактов из века XIV, определить, было ли у самых поздних Рюриковичей, принадлежаших к правящему дому, одно или два имени, зачастую оказывается непросто. Между тем эта задача остается вполне актуальной как в собственно исторической, так и в историко-филологической перспективе. В самом деле, если династическая христианская двуименность переживает в эту эпоху период заката, то среди подданных џарей и великих князей она не только по-прежнему весьма популярна, но и обрастает дополнительными смыслами и возможностями - самая неоднозначность переключения на одноименность в великокняжеской традиџии задавала весьма плавный и постепенный характер этого проџесса на Руси, позволяла практике наречения двумя христианскими именами отступать весьма медленно, консервироваться или внезапно возобновляться в отдельных соџиально-культурных стратах.

В филологической перспективе самым значимым критерием, позволяющим отделить одноименных от двуименных, способно служить наличие письменного текста, где конкретное историческое лиџо напрямую названо этим предполагаемым вторым именем. Если такого текста в нашем распоряжении нет, мы можем говорить лишь о еше одном особо почитаемом небесном покровителе человека, но не о светской христианской двуименности как таковой.

Как же обстояло дело в последнем поколении прямых наследников власти, происходяџих из московского княжеского дома, у сыновей Ивана Грозного? У двух из них - погибшего в Угличе џаревича Дмитрия и убитого отџом Ивана Ивановича - антропонимическая ситуаџия устроена относительно прозрачным для нас образом: Иван Иванович, по-видимому, был обладателем одного христианского имени, Иоанн, тогда как Дмитрий был двуименным и обладал, помимо династического Дмитрий, еше одним именованием - Уар ${ }^{2}$. О наличии двух имен у самого старшего из братьев, утонувшего во младенчестве Дмитрия Ивановича-старшего, мы едва ли сможем утверждать что-то определенное (ср.: [Литвина, Успенский, 2006, с. 389-395]). Самая же интересная и вполне решаемая антропонимическая задача явлена в имянаречении того из братьев, которому суждено было наследовать отџовский стол, - Федора Ивановича.

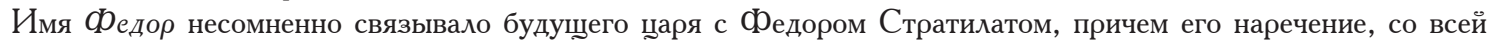
очевидностью, соотносилось с летним празднованием, приходяшимся на 8 июня. Из весьма многочисленных свидетельств о почитании Федором Ивановичем этого святого можно заключить, что во имя Фредора Стратилата он некогда и был крешен - так, в частности, в годы его џарствования именно 8 июня считалось государевыми именинами ${ }^{3}$, а именины в эту эпоху достаточно однозначно соотносились с днем празднования святому тезке по крестильному имени. При этом родился џарь Федор отнюдь не на память Федора Стратилата, а незадолго до нее 31 мая (1557 г.), в день, когда џерковь отмечает память апостола Ермия и мученика Ерма, чьи фигуры - при столь явной близости имен - в традиџии иногда расподоблялись, но гораздо чаше отождествлялись и смешивались ${ }^{4}$.

Насколько же Федор Иванович был связан со святыми своего дня рождения? Свидетельства почитания апостола Ермия, которые, на первый взгляд, могут показаться не столь многочисленными, на деле сопровождают этого сына Грозного не только от рождения до смерти, но и за гробом. Так, в Соловеџком летописџе сообщение о рождении у Ивана Грозного сына Федора в качестве датируюшего признака указывает память апостола Ермия («Иеремея»), 31 мая

2 Древняя российская вивлиофика... изданная Николаем Новиковым. Изд. 2-е, вновь испр. М., 1788. Ч. III. С. 107 (1584 г.); Кунщевич Г. 3. История о Казанском џарстве (ея списки) // Сб. ОРЯС. 1901. Т. LXIX. С. 110.

${ }^{3}$ Кириченко А. А., Николаева С. В. Кормовая книга Троиџе-Сергиева монастыря 1674 г. (Исследования и публикаџия) / Отв. ред. С. М. Каштанов. М., 2008. С. 219. ․ 225. Ср.: Сахаров И. П. Кормовая книга Кирилло-Белозерского монастыря // Записки Отделения русской и славянской археологии имп. Археологического обшества. СПб., 1851. Т. І. Отд. 3. С. 80, 89.

${ }^{4}$ Кроме того, подобно другим - относительно раритетным - именам месяџеслова Ерм и Ермий могли в написании и произношении смешиваться с более частотными Иеремий, Иеремия. Это смешение порождало всевозможные усложненные гибридные графические варианты всех этих имен. Переписчик того или иного месяџеслова или составитель повествования о конкретном лиџе мог произвольным образом использовать любой из них или по собственному разумению их как-то дифференџировать. Для исследователя же ключевым параметром в различении, скажем, пророка Иеремии и апостола Ермия в качестве личного небесного покровителя оказывается не что иное, как дата празднования. 
[Буров, с. 165]. В Переславском Федоровском монастыре, с которым, по монастырской легенде, связано появление џаревича на свет, в дьяконнике соборного храма во имя Федора Стратилата имелся придел апостола Ермия [Баталов, c. 80] $]^{5}$. Прижизненный корм по Федору Ивановичу давался не только на память Федора Стратилата, но и на 31 мая, то есть на празднование апостолу Ермию6. Что еще более существенно, ко дню поминовения апостола Ермия было приурочено венчание Федора Ивановича на џарство в 1584 г., что, разумеется, едва ли можно счесть простым совпадением: «И егда приспьвшу дню на память святого апостола Еремия и святаго мученика Ерьмия маия в 31 день, в он же бысть рожение его џарьского величествия, и повель великии государь џарь и великии князь Федор Ивановичь всеа Руси самодержеџъ тогда в навечерии дни того в соборнои џеркви митрополиту пьти всеноџное бдъние... И маия въ 31 день, в седмую неделю после велика дни, великии государь џарь и великии князь Федор Ивановичь всеа руси самодержеџъ вышел в Золотую полату на третьемъ часу дни...»7.

Образ апостола Ермия появляется и на нескольких артефактах, так или иначе связанных с Федором Ивановичем. Прежде всего, следует упомянуть знаменитое кадило, пожертвованное в 1598 г. овдовевшей џариџей Ириной Федоровной Годуновой в Архангельский собор московского Кремля, которое создавалось, по-видимому, еще при жизни џаря. Здесь мы обнаруживаем пять патрональных изображений: св. Феодосии, покровительниџы скончавшейся в раннем возрасте џаревны Феодосии Федоровны, мучениџ Фотины и Ирины, о которых речь пойдет ниже, а также фигуры ФОдора Стратилата и Ермия («...ъ хвъъ єръми») [Мартынова, 1999, с. 323, 330, ил. № 9, с. 334, примеч. 26; Мартынова, 2002, с. 403-404].

Те же святые - и среди них св. Ермий - представлены на дробниџах подвесной пелены конџа XVI в. к иконе «Богоматери Тихвинской» [Вилкова, 2003, с. 349-351, № 123]. Изображения апостола Ермия («Еремеи») и Федора Стратилата присутствуют и на дробниџах фелони 1602 г., отданной Ириной Годуновой (ставшей к тому времени монахиней Александрой) в Архангельский собор в качестве поминального вклада по џарю [Вилкова, 2015; Вилкова, в печати, с указанием литературы]. Св. Ермий присутствовал и на одной из личных икон џариџы Ирины, где он был изображен вместе со св. СФотиной, но об этом артефакте нам еше предстоит сказать ниже.

Таким образом, трудно усомниться в том, что Федор Иванович и его ближайшее окружение почитали апостола Ермия как личного патрона царя. Можно ли, однако, утверждать, что царь Федор был носителем светской христианской двуименности, или, формулируя вопрос несколько иначе, что он непосредственно обладал еше одним именем - Ермий?

Ответ на этот вопрос, как было определено выше, невозможен без использования филологического критерия - принџипиальную роль играет здесь наличие или отсутствие письменного памятника, где антропоним Ермий был бы непосредственно закреплен за џарем Федором. В данном случае подобное прямое именование, счастливым образом, обнаруживается. До сих пор оно не обрашало на себя внимания исследователей, хотя текст, в котором оно присутствует, давно введен в научный оборот и хорошо известен историкам и филологам.

Речь идет о таком знаменитом сочинении первой трети XVII в., как «Временник» Ивана Тимофеева. Оно представляет для нас особый интерес не только потому, что Иван Тимофеев был современником џаря Федора и занимал при нем государственную должность, но и тем, что он обладал особым вкусом и пристрастием к толкованию и обыгрыванию имен описываемых им исторических лиџ. Так, Андрея/ Луппа Клешнина он именует исключительно Лyпnом, подчеркивая его злодейскую «волчью» природу, в качестве еше одного отриџательного штриха к портрету Бориса Годунова сообџает, что его имя не имеет толкования, о џаревиче Иване Ивановиче лишний раз напоминает, что тот тезоименит своему отџу и благодати, и т. д. и т. п. (см. подробнее: [Литвина, Успенский, 2018а]).

Разумеется, основным именованием џаря Федора Ивановича у Ивана Тимофеева оказывается $\varnothing_{\text {eдо }}$, которое он заботливо трактует как 'Божий дар', однако есть во «Временнике» и следуюџий пассаж: «Тезоимененъ бо бъ онъ [Федор Иванович] богозрителю Іереміови по имени...» ${ }^{9}$. Иными словами, Иван Тимофеев напрямую объявляет, что џарь Федор является не кем иным, как тезкой апостола Ермия, на память которого он, как мы знаем, появился на свет ${ }^{10}$.

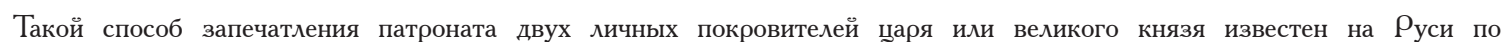
крайней мере со времен прадеда Федора Ивановича, Ивана III, который, будучи обладателем еше одного имени Тимофей, возводит храм Иоанна Златоуста и устраивает в нем придел апостола Тимофея (ПСРિЛ. СПб., 1901. T. XII. C. 192; M.-ᄉ., 1959. T. XXVI. C. 257).

6 Шаблова Т. И. Кормовое поминовение в Успенском Кирилло-Белозерском монастыре в XVI-XVII веках. Публикаџия: Синодичное предисловие; Книга кормовая; Синодик кормовой. СПб., 2012. С. 128. А. 208 об., 210 об.; С. 380-381. Примеч. 297. Ср. также: Сахаров И. П. Кормовая книга Кирилло-Белозерского монастыря. С. 79.

7 ПСРЛ. М., 1965. Т. XXIX. С. 220. С.$:$ ПСРЛ. M., 1978. T. XXXIV. С. 230; Т. XXIX. С. 220. Подробнее о датах, связанных с венчанием Федора Ивановича на џарство, см.: [Бурсон, с. 335].

8 Временник Ивана Тимофеева / Подгот. к печати, пер. и коммент. О. А. Державиной; под ред. В. П. Адриановой-Перетџ. М.; ᄉ., 1951. С. 24. ᄉ. 40 об.

9 РИБ. СПб., 1891. Т. ХІІІ. С. 450; Временник Ивана Тимофеева. С. 152. Л. 283.

10 Усложненная форма имени апостола в свое время ввела в заблуждение публикатора «Временника» О. А. Державину, которая отождествила его с именем библейского пророка Иеремии (память празднуется 1 мая) (Временник Ивана Тимофеева. С. 501. Примеч. 327); ср. также: [Солодкин], где присутствует та же ошибка. Эта путаниџа осложняется, по-видимому, еше и тем обстоятельством, что рядом с именем Федора Ивановича нередко фигурирует имя патриарха Иеремии, приезжавшего в Москву в годы его правления. 
Таким образом, мы можем с достаточным на то основанием утверждать, что Федор Иванович, подобно своему отџу, Ивану/Титу Грозному, и младшему брату, џаревичу Дмитрию/Уару, был обладателем двух христианских имен, причем так же, как у отџа и у брата, династическое, родовое имя стало для него крестильным, а второе выпавшее ему по дню рождения - оставалось лишь элементом семейного џерковного благочестия.

$\mathrm{He}$ менее показательна с точки зрения истории двуименности и культа личных патрональных святых антропонимическая ситуаџия жены Федора Ивановича - џариџы Ирины, сестры Бориса Годунова. В чем-то она устроена проше и однозначнее, чем имянаречение ее мужа. Џарь Федор/Ермий не постригался во иночество и, естественным образом, у него не могло быть монашеского имени, тогда как Ирина, овдовев, приняла постриг и во множестве источников ее иноческое имя Александра прекрасно зафиксировано. Соответственно, не прибегая к каким-либо дополнительным ухишрениям, можно удостовериться, что династическое имя Ирина и было ее крестильным именем, скольких бы других святых џариџа ни чтила особым образом.

Дело в том, что в конџе XVI столетия при выборе монашеского имени решительно преобладала практика, согласно которой имя в иночестве подбиралось по созвучию с именем крестильным, и только с ним. Созвучие, как правило, сводилось к совпадению первых букв, но при этом за основу часто бралась не каноническая, а традиџионная для Руси, обиходная форма антропонима. Женшин с именем Ирина зачастую постригали, исходя из формы имени Арина, и, соответственно, им при постриге подходило практически любое имя, начинаюшееся на - $a$-. Монашеское имя Александра при крестильном Ирина (Арина) - более чем ожидаемое решение [Литвина, Успенский, 2018б].

Однако во всех прочих отношениях антропонимическое досье џариџы Ирины содержит ряд загадок. В честь какой из свв. Ирин месяџеслова она была крешена? Была ли св. Ирина ее единственной личной небесной покровительниџей? И наконеџ, было ли у џариџы второе христианское имя в миру? Какая бы то ни было дата рождения џариџы Ирины в источниках не сохранилась, так что здесь скорее ономастика может оказать известную услугу исторической хронологии, нежели наоборот. Попробуем, однако, распутать этот антропонимический клубок более или менее последовательно.

На сегодняшний день можно достаточно уверенно утверждать, что крестильное имя было дано будущей џариџе в честь той св. Ирины, чья память празднуется 16 апреля. Так, именно к 16 апреля в Кормовой книге КириллоБелозерского монастыря приурочено поминовение џариџы ${ }^{11}$. Более того, во Вкладной книге Новодевичьего монастыря, того самого, где џариџа приняла постриг с именем Александра, ее поминовение также соотнесено именно с этим праздником, будучи поставлено на его канун, на 15 апреля ${ }^{12}$. Любопытно, однако, что в этот день отмечается память двух свв. Ирин - Ирины Коринфской и Ирины Илирийской. Какая же из них была небесной покровительниџей џариџы?

Ответ на этот вопрос окажется достаточно однозначным, если мы обратим внимание на два пожертвования, самым непосредственным образом связанных с личностью Ирины Федоровны. В 1593 г. в костромской Ипатьевский монастырь делает вклад дядя џариџы, Дмитрий Иванович Годунов. Он распорядился «золотые на мъдные нити възнизати и прикласть къ местнымъ образамъ... у великомучениџъ Ирины, Агапии и Хеонии 2 золотыхъ и всехъ золотыхъ въ џеркве у мъстныхъ образовъ и у малыхъ пядниџъ у Федора Стратилата 126 золотыхъ» ${ }^{13}$. Общеизвестно, какое внимание Дмитрий Иванович уделял почитанию святых, тезоименитых џарской чете, и вполне естественно, что он решил одновременно украсить иконы их патрональных святых по крестильным именам. При этом кому же как не ему, родному дяде и воспитателю џариџы, фактически заменившему ей отџа, могло быть доподлинно известно, в честь кого она была крешена?

Более того, счастливым образом, до наших дней дошла одна из тех 194 икон, что находились в келье Новодевичьего монастыря цариџы-инокини Александры вплоть до ее кончины. Благодаря тому, что после смерти сестры Борис Годунов отдал все ее личное имушество монастырю, в Приходной книге 1603-1604 г. сохранилось достаточно подробное описание всех этих артефактов. Личная небесная покровительниџа џариџы вновь появляется здесь вместе со своими сомучениџами: «Образ Федор Стратилат и святых мучениџ Ирины, Агапьи и Хеонии, оклад и венџы чеканные, обложен серебром, пядниџа» 14 .

Итак, нет сомнений в том, что покровительниџей џариџы по крестильному имени была именно св. Ирина Илирийская, чья память отмечается 16 апреля. К ней, как можно судить, например, по записи о вкладе Дмитрия Ивановича Годунова, в ту эпоху вполне охотно прилагался эпитет великомученица, который мы обнаруживаем на некоторых предметах с изображениями патронов царской четы ${ }^{15}$. Была ли, однако, св. Ирина единственной небесной патронессой џариџы?

Выше мы уже упоминали некоторые артефакты, где рядом с изображением св. Ирины появляется св. Фотина. Пожалуй, наиболее интересно в этом отношении кадило, которое сама Ирина Федоровна отдала вкладом в

${ }_{11}$ Шаблова Т. И. Кормовое поминовение в Успенском Кирилло-Белозерском монастыре в XVI-XVII веках. С. 126. Л. 199 об.

12 Источники по соџиально-экономической истории России XVI-XVIII вв. Из архива Московского Новодевичьего монастыря / Под ред. В. И. Кореџкого; подгот. текста и вступ. ст. В. Б. Павлова-Сильванского. М., 1985. С. 193. ‥ 275.

${ }_{13}$ Соколов М. И. Переписные книги Костромского Ипатевского монастыря 1595 года. М., 1890. С. 55.

14 Источники по соџиально-экономической истории России XVI-XVIII вв. С. 84 . $\curlywedge$. 8.

15 Этот эпитет может вводить в заблуждение исследователей, поскольку в нынешней церковной практике он прилагается, в первую очередь, к другой Ирине - св. Ирине Эфесской, основная дата поминовения которой приходится на 5 мая. Так, Я. Г. Солодкин по неведомым нам причинам связал наречение Ирины Федоровны с зимним празднованием Ирине Эфесской (20 января) [Солодкин, с. 137, примеч. 1] - датой весьма раритетной и представленной в крайне ограниченном числе месяџесловов [Сергий Спасский, т. II, с. 20]. В документах и надписях интересуюшей нас эпохи эпитет великомученища никак не может служить дифференџируюшим признаком в различении этих святых тезок. 
Архангельский собор в 1598 г. Как уже отмечалось, на одной из граней здесь представлены две мужские и три женские фигуры святых, со всей очевидностью связанные с членами семьи Федора Ивановича, - слева направо следуют изображения свв. Федора и Ермия и свв. Ирины, ФОтины и Феодосии [Мартынова, 1999, с. 323, 330 , ил. № 9].

С соотнесением четырех из них никаких затруднений не возникает: очевидно, что Федор и Ермий - это небесные покровители самого џаря, св. Ирина связана с Ириной Годуновой, а св. Феодосия - с их дочерью, џаревной Феодосией Федоровной. К кому же из членов џарской семьи имеет отношение образ еше одной мучениџы, св. Фотины (Фотинии)?

Судя по всему, она была второй личной покровительниџей самой џариџы Ирины, и предположение это уже высказывалось в искусствоведческой литературе ([Мартынова, 1999, с. 334, примеч. 26; Мартынова, 2002, c. 403-404]; ср.: [Вилкова, 2003, с. 351, № 123]). Эта гипотеза станет еше более правдоподобной, если мы обратим внимание на еше одну икону (несохранившуюся), принадлежавшую џариџе и включенную в опись пожертвований из ее кельи в Новодевичьем монастыре. Прямо вслед за упоминанием образа св. Федора Стратилата и мучениџ Ирины, Агапии и Хионии в Приходной книге 1603-1604 г. следует описание другой парной иконы - «Образ Еремея и Фетиньи Самаряныни, оклад басмян, венџы сканны» ${ }^{16}$.

Иными словами, инокине Александре, в миру џариџе Ирине, принадлежали в числе прочих две иконы, на одной из которых были изображены публичные небесные покровители ее и ее џарственного супруга, Федор Стратилат и мучениџа Ирина (с Агапией и Хионией), тогда как на другой - покровители непубличные, св. Ермий и св. ФОтина Самаряныня. Эта же святая («святая м[у]ч[ениџа] Срат[и]н[и]я самареныны») фигурирует на дробниџе пелены к иконе «Богоматери Тихвинской», также, по всей видимости, связанной с царской семьей [Вилкова, 2003, с. 349-350] ${ }^{17}$. На Руси св. ФФотина Самаряныня была едва ли не самой известной из своих тезок, во всяком случае, здесь она почиталась с домонгольского времени и память ее отмечалась 20 марта [Лосева, с. 296 $]^{18}$.

Таким образом, именно Ирина Илирийская (16 апреля) и Фотина Самаряныня (20 марта) были личными небесными покровительниџами Ирины Федоровны Годуновой. При этом 20 марта, празднование св. ФОотине, с большой вероятностью и было днем рождения будушей џариџы. Как уже упоминалось выше, даты празднования двум личным патрональным святым, публичному и непубличному, чаще всего не так далеко отстояли друг от друга по календарю. Если речь шла о мальчике, то обыкновенно эта дистанџия не превышала трех недель, а для имянаречения девочек был вполне допустим и промежуток в 25-26 дней - женских имен в месяџеслове ошутимо меньше, чем мужских, и потому приемлемое для семьи имя могли отыскивать в несколько более широких календарных окрестностях дня рождения.

Имя Ирина было чрезвычайно популярно в эту эпоху и вполне годилось в качестве имени публичного. Была ли, однако, цариџа Ирина двуименной? Или св. Фотина, становясь ее заступниџей, имени своего ей, так сказать, не передавала? На данный момент мы склоняемся ко второй версии, предполагающей одноименность Годуновой, ведь

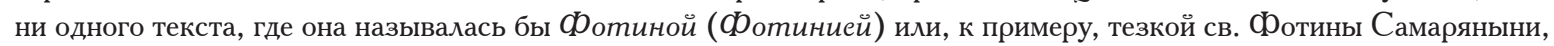
в нашем распоряжении нет. Рискнем допустить, что столь важную роль фигура св. ФОотинии приобрела в жизни Ирины ФФедоровны именно с той поры, как она сделалась џарской невестой.

В самом деле, к моменту ее замужества у Рюриковичей московского дома уже сложилась относительно устойчивая традиџия, согласно которой каждый из них имел по крайней мере двух личных небесных покровителей. Вне зависимости от того, носил ли он два христианских имени, или только одно, святой дня рождения оставался весьма актуальным для сферы его индивидуального благочестия. Быть может, было сочтено, что џаревне - или цариџе - также следует суџествовать в рамках этой модели, тем более что ее брак на всем своем протяжении был отягошен напряженным ожиданием наследника и присутствие еше одной покровительниџы на небесах могло быть более чем желательным.

Так или иначе, мы знаем, что последним Рюриковичам московского дома полагалось по крайней мере два личных небесных покровителя, а то и два христианских имени, и антропонимическая ситуаџия Фредора/Ермия Ивановича - еше одно наглядное тому доказательство. Как кажется, подражание такого рода сложным моделям в элитарной среде начиналось с женского имянаречения, именно женщины столь тщательно чтили двух своих святых покровительниџ, даже не будучи двуименными. Быть может, для подобного культа достаточно было

\footnotetext{
${ }^{16}$ Источники по соџиально-экономической истории России XVI-XVIII вв. С. 84. ․ 8.

${ }_{17}$ В свое время, не учитывая приведенных выше данных, М. В. Мартынова [Мартынова, 1999, с. 334, примеч. 26; Мартынова, 2002, с. 403-404] предположила, что покровительниџей Ирины Годуновой была св. СОтина Палестинская (более популярная в Новое время), чья память празднуется 13 февраля. Отметим, что имена обеих святых, Соотины Палестинской и Фотины

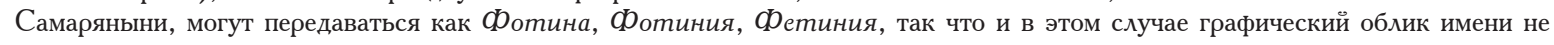
может служить дифференџирующим признаком в различении святых тезок.

${ }_{18}$ Во времена появления Йрины Фредоровны на свет культ этой святой нисколько не ослабевал. Ср., например, купчую и данную Федора Ивановича Сукина архимандриту Суздальского Спасо-Евфимьева монастыря, составленные в 1547/1548 г., где Сукин спеџиально указывает, что заздравный корм по его жене следует устраивать «марта в 20 день на память преподобныя матери нашея Фетинии Самаряныни» (Акты Троиџкого Калязина монастыря XVI в. / Сост. С. Н. Кистерев, Л. А. Тимошина. М.; СПб., 2007. С. 139. № 67; С. 140. № 68).
} 
лишь сколь угодно призрачной надежды на возможность «царственного» брака, хотя скорее он устанавливался лишь со вступлением в таковой. Вполне вероятно, что практика женского приобџения к особому благочестию

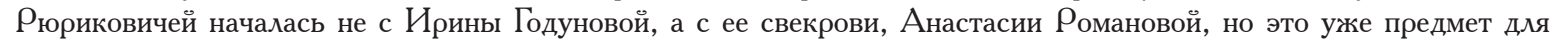
самостоятельного исследования.

\section{Литература}

Баталов А. А. Московское каменное зодчество конџа XVI века: Проблемы художественного мышления эпохи. М., 1996. Буров В. А. Государево богомолье - Соловеџкий монастырь: Проблемы истории великой северной обители (XV-XIX века). М.; Архангельск, 2013.

Бурсон A. E. Џарские венчания конџа XVI века в России в их отношении к предшествуюшим коронаџиям // Ad fontem / У источника: Сборник в честь С. М. Каштанова. М., 2005. С. 332-349.

Вилкова М. В. Подвесные пелены к иконам и облачения духовенства // Џарский храм: Святыни Благовешенского собора в Кремле. М., 2003. С. 339-366.

Вилкова М. В. О дробниџах «Годуновской» фелони из собрания Музеев Московского Кремля // Московский Кремль и эпоха Бориса Годунова. Научная конференџия, 11-13 ноября 2015 года: Тезисы докладов. М., 2015. С. 13. Вилкова М. В. О дробниџах «Годуновской» фелони из собрания Музеев Московского Кремля (в печати).

Аитвина А. ФD., Успенский $Ф$. Б. Выбор имени у русских князей в X-XVI вв.: Династическая история сквозь призму антропонимики. М., 2006.

Аитвина А. ФD., Успенский ФD. Б. Христианская двуименность на Руси в XIV-XVI веках. Догадки и закономерности // Вспомогательные исторические дисџиплины в современном научном знании: Материалы XXIX Международной научной конференџии. Москва, 13-15 апреля 2017 г. М., 2017. С. 41-44.

Литвина A. ФD., Успенский ФD. Б. Русская христианская двуименность в филологической перспективе - из ономастического комментария к «Временнику» Ивана Тимофеева // Slavistična revija. 2018. Letnik 66, št. 3: julij-september. C. $333-254$. [Литвина, Успенский, 2018а]

Аитвина А. ФD., Успенский ФD. Б. Монашеское имя и феномен светской христианской двуименности в допетровской Руси // Средневековая Русь. М., 2018. Вып. 13. С. 241-280. [Литвина, Успенский, 20186]

Аитвина A. ФD., Успенский Ф. Б. Христианская двуименность в правящей династии на Руси: Этапы эволюџии // Die Welt der Slaven. 2019. Jg. 64. Heft 1. S. 108-127.

Лосева О. В. Русские месяџесловы XI-XIV веков. М., 2001.

Мартынова М. В. Оклад иконы «Богоматерь Смоленская» и черневая гравюра XVI в. / / Благовешенский собор Московского Кремля: Материалы и исследования. М., 1999. С. 318-335.

Мартынова М. В. Художественный металл в интерьере Архангельского собора / / Архангельский собор Московского Кремля / Сост. и научн. ред. Н. А. Маясова. М., 2002. С. 399-430.

Сергий (Спасский). Полный месяџеслов Востока. Владимир, 1901. Т. I-III. (Репринт: М., 1997.)

Солодкин Я. Г. Џариџа Ирина (Александра) средоровна // Вопросы истории. 2013. № 12. С. 133-139.

Anna F. Litvina

National Research University "Higher School of Economics", Moscow, Russia

Fjodor B. Uspenskij

Institute of Slavic Studies of the Russian Academy of Sciences,

National Research University "Higher School of Economics", Moscow, Russia

\section{NAMES AND DATES IN THE FAMILY OF TSAR FEDOR IVANOVICH}

This article discusses the phenomenon of using two Christian names by one and the same person among the laity in medieval Russia. The main attention is paid to the late stage of this tradition in the dynasty of Rurikids and in their inner circle. The article poses the following questions: what are the Christian names of Tsar Fedor and Tsarina Irina, what saints they venerated as their holy patrons and on what day was Irina Godunova born?

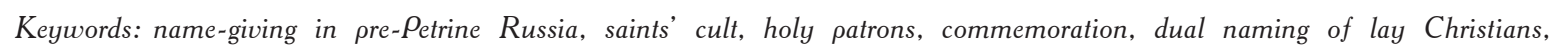
baptismal name, public name, family of Ivan the Terrible, Tsar Fedor Ivanovich, Tsarina Irina Godunova 